\title{
Use of Variators in Applying the Cost Calculation Methodology in Small and Medium Furniture Enterprises Based on Changes in Human Body Dimensions
}

\section{Primjena varijatora korištenjem metodologije izračuna troškova u malim i srednjim tvrtkama za proizvodnju namještaja na temelju promjena dimenzija ljudskog tijela}

\author{
Original scientific paper • Izvorni znanstveni rad \\ Received-prispjelo: 13. 11. 2017. \\ Accepted-prihvaćeno: 10. 12. 2018. \\ UDK: $630 * 836.1 ; 630 * 79$ \\ doi: $10.5552 /$ drvind.2019.1763
}

\begin{abstract}
Based on the research of anthropometric measures of Slovak adult population, it can be observed that during the last 25 years, anthropometric data have been rising by about 4.5-5\% in most analysed characters. As data on human body dimensions changes, the requirements for material consumption and production time, expressed by the rate of labour cost, are changing. In this context, sustainable profitability of the company can be achieved through each segment of a value chain. One of these segments is the product and its price, which is based on costs allocated in the system of full or variable costing. As the value of quantiles characteristics of anthropometric characters was used to create ergonomic, health and construction norms and standards in the furniture industry, it is necessary to review the adequacy of existing standard-size single bed. Since the dimensions of single bed are standardised, $200 \mathrm{~cm} \times 90 \mathrm{~cm}$ or $200 \mathrm{~cm} \times 100 \mathrm{~cm}$, it is clear that due to the secular trend of anthropometric measure of a man, the dimensions are currently inadequate. This paper presents the use of variators when applying the most commonly used absorption costing in small and medium furniture enterprises. It shows the costs involved, when the input parameters are changed.
\end{abstract}

Key words: innovation, calculation, bed furniture, variator, SMES

\footnotetext{
Authors are associate professors at Technical University in Zvolen, Faculty of Wood Science and Technology, Zvolen, Slovakia. ${ }^{2}$ Authors are assistant professors at Technical University in Zvolen, Faculty of Wood Science and Technology, Zvolen, Slovakia. ${ }^{3}$ Author is professor at Faculty of Management, Comenius University in Bratislava, Bratislava, Slovakia.

Autori su izvanredni profesori Tehničkog sveučilišta u Zvolenu, Fakultet znanosti o drvu i drvne tehnologije, Zvolen, Slovačka. ${ }^{2}$ Autori su docenti Tehničkog sveučilišta u Zvolenu, Fakultet znanosti o drvu i drvne tehnologije, Zvolen, Slovačka. ${ }^{3}$ Autor je profesor Fakulteta za menadžment, Sveučilište Comenius u Bratislavi, Bratislava, Slovačka.
} 
SAŽETAK • Na temelju istraživanja antropometrijskih mjera slovačke populacije odraslih možemo primijetiti da su se u posljednjih 25 godina antropometrijski podatci o većini analiziranih značajki povećali oko 4,5 - 5 \%. Kako su se mijenjale dimenzije ljudskog tijela, tako se mijenjala i potrošnja materijala te vrijeme proizvodnje, što je izraženo udjelom troškova rada. U tom kontekstu održiva se profitabilnost tvrtke može postići putem svakog dijela lanca vrijednosti. Dio lanca vrijednosti čine proizvod i njegova cijena, koja se temelji na troškovima dodijeljenima u sustavu potpunih ili varijabilnih troškova. Budući da je vrijednost kvantitativnih antropometrijskih značajki iskorištena pri izradi ergonomskih, zdravstvenih i konstrukcijskih normi u industriji namještaja, potrebno je razmotriti adekvatnost dimenzija postojećega standardnog kreveta. S obzirom na to da su standardizirane dimenzije kreveta za jednu osobu $200 \mathrm{~cm} \times 90 \mathrm{~cm}$ ili $200 \mathrm{~cm} \times 100 \mathrm{~cm}$, jasno je da zbog sekularnog trenda čovjekovih antropometrijskih mjera današnje mjere standardnog kreveta više nisu adekvatne. U članku se prikazuje primjena varijatora u najčešće korištenim metodama ukupnih troškova u malim i srednjim poduzećima za proizvodnju namještaja. Također se prikazuju troškovi pri promjeni ulaznih parametara.

Ključne riječi: inovacija, izračun, kreveti, varijator, mala i srednja poduzeća

\section{INTRODUCTION} 1. UVOD

Small and medium-sized enterprises (SMEs) represent a significant part of the economy and industrial system of every country (Buehlmann et al., 2013; Bumgardner et al., 2011). In the European Union, as well as in the Slovak Republic, SMEs represent more than $99 \%$ of the total number of business entities (Slovak Business Agency, 2016). Globalization is putting the pressure on furniture SMEs to achieve innovation and modernization of technological and manufacturing processes (Barčić et al., 2016; Tokarčíková and Kucharčíková, 2015).

In order to be successful in the market and to increase the competitiveness, the main role of the company is to come up with product innovations. An economic aspect is another non-negligible challenge, too. When designing housing, it is necessary to consider the basic biological needs of humans, the quality of the environment, as well as microclimatic, acoustic, optical and environmental hygiene. Therefore, it is essential to take into account the dimensions of the human body and the resulting spatial needs necessary for the performance of housing-related activities. Spatial needs and parameters for performing activities in the apartment are derived from the average body dimensions of people. However, when identifying a particular client, it is necessary to take into account his/her individual needs. Changing anthropometric parameters of a person are associated with the development and growth of generations - the secular trend. It means the change in physical dimensions between the past and present generations at the same age range. These changes do not occur suddenly but over a long-term development in one and the same territory. It is the result of improving health care, increasing the quantity, quality and availability of food, mixing ethnicity and peoples, various psychosocial changes. The secular trend is best observed when considering the human body height. Based on previous findings, it can be stated that secular trend was, on average, confirmed by $1.55 \mathrm{~mm}$ per year (Sedmák and Hitka, 2007).

The bed is the basic object of residential equipment. High quality demands are placed on bedding furniture. People spend a third of their life on it. From the point of view of anthropometry, physiology and hygiene, the size of the bed must be suitable for the human body taking into account the fact that the body position changes during sleep. From the anthropometric point of view, the length, width and height of the bed area is particularly important (Hitka and Hajduková, 2013; Kotradyová and Kaliňáková, 2014).

The production of furniture specific for residential space is an issue that humanity has been dealing with since prehistoric times. Primitive people created various primitive tools. Even in this activity, a man needed to sit comfortably. In ancient Egyptian times, people already thought about the way how to adapt furniture to man and his needs. A seat with a slightly inclined backrest was made for a more comfortable seating in ancient Egypt times. At the same time, the first stool was made in the form that is still used nowadays. The Rococo period, called as the style of the interior, brought other revolutionary changes. People were looking for ways how to sit comfortably for hours without pain. Gradually, serial furniture production was introduced because production was not economic. During the 2nd World War, it was possible to buy modern furniture with ergonomic shaping (Peteri, 2017; Kolena and Vodráková, 2013).

In Europe, Scandinavia has become the best country in the whole furniture production market, perhaps because the country was not hit by the war as much as most other European countries. Designers adapted to new knowledge in the field of sociology. Slowly, the first housing developments were built, requiring furniture to be adapted. At that time, everyone could buy furniture, especially because of large-scale production. It was not necessary to use inherited furniture. Thanks to this phenomenon, every family could change the furniture several times. On the other hand, the furniture was not of high quality. Later, aesthetic and emotional aspects have begun to be added. Seating furniture had becoming more and more suited to the human body (Veselovský and Kotradyová, 2009). Based on these trends, the furniture began to be broken down according to the activity it was used for. During the past decade, ergonomic research focused especially on the design of work furniture based on the biomechanics of the human body. Many researchers dealt with the principles for the design of chairs and desks in 
the workplace, particularly for computer system users (Burgess-Limerick et al., 1999; Cook and Kothiyal, 1998; Aaras et al., 1997; Villanueva et al., 1996; Kumar, 1994; Naqvi, 1994). In the field of interior and furniture design, comfort was based on correct dimensions of the user or group of users. Over the last millennium, man was physically developing. This is indicated by the skull, denture, and post-skeletal skeleton, decreasing body weight and brain capacity. Changes in furniture dimensions are visible in the history of architecture and furniture development, too (varying the height of holes, ceilings, etc.). Since the Neolithic period, Europeans are still subject to the conformationalheterogeneous trend (Kolena and Vodráková, 2013). This trend is manifested by different features of the body, which are being simulated by Europeans. It is well known that the environment has a significant impact on these changes. Therefore, planners, designers and engineers should be aware of the space occupied by a person in different positions, and they should provide safety for movement and relaxation (Smardzewski, 2009).

Body dimensions, such as average body height, vary and develop in time (in comparison with the past, body dimensions are greater) (Ozer, 2007; Carrascosa et al., 2004; Malina et al., 2004; Krawczynski et al., 2003). For example, the length of the bed has increased considerably since the Middle Ages. In addition to the increase in body height and weight, the differences in geographic segmentation increased, too. Nowadays in Europe, dimensional standards applicable to architecture and furniture industry cannot be unified because of significant differences in the population, especially between Southern, Northern and Central European regions. The European Union's attempt to introduce uniform dimensional standards has proven to be unrealistic. The market hits the conservatism of society as a whole. Reactions to these facts are very slow. It can be seen in sectors where consumption is a major economic factor, for example the automotive industry, aerospace industry, textile industry and shoe industry (Woolliscroft et al., 2015).

In literary sources, the structure of calculation formula can be found (Lazar, 2012; Poniščiaková, 2010; Popesko, 2009). It is the so called general calculation formula as the starting basis for calculation formulas for different conditions (Hradecký et al., 2008). The general calculation formula includes direct and indirect (overhead) costs. Overhead costs represent a significant part of total costs (Synek et al., 2007). Therefore, it is important to manage them and to define their roles so as to reduce them. Costs contribute to the economic growth, because costs are one of the main sources of its reduction. For practical management of costs, it is necessary to implement the classification of costs. It is necessary to consider the type of production, technology used, organization of internal departments. The general calculation formula is used in the methodology of absorption calculation. The absorption calculation implies a number of limitations (Popesko, 2009). These limitations are based on increasing inaccuracies, caused by disproportionate cost allocation. According to the author, this uncertainty is deepening in the context of historical changes in the share and structure of overhead cost.

The problematic factor is still the allocation of overhead costs. Variators can be used for the process of planning overhead costs (Synek et al., 2007). The values give information on the percentage of costs increase, if performance or other value is increased by 1 $\%$. They are determined as the share of variable costs in the total overhead costs as a relevant share of the specific group of overhead costs. This share reaches values in the range from zero, when all costs are fixed, eventually to one, where all costs can be considered as variable items. Thus the zero variator is the item of centre budget and its costs are total fixed costs in relation to its activity (Hradecký et al., 2008). On the other hand, a variator equal to one determines costs that grow proportionally with the change of the centre size activity. The variator can be expressed as "centesimal", "decimal", and sometimes even as "unit" (Lazar, 2012).

Since man is considered the scale of all things, its physical dimensions are used as the basis for all measurements. The physical dimensions are very important because small changes can have a considerable impact on health, safety, and productivity (Mokdad, 2002). The last and still used anthropometric database of our population comes from the times of Czechoslovakia. Nowadays, most of the norms and standards are based on data measured before 1955, and therefore workplace parameters are inappropriate (Kovařík, 2009; Cvičelová et al., 2005). Norms and standards are outdated and, moreover, physical dimensions of each new generation are higher than those of their ancestors. The increase is significant in the long term. In general, as the statistics show, young men are higher than their fathers by about $4.5 \mathrm{~cm}$, and higher than their grandfathers up to $7.5 \mathrm{~cm}$ (Kolena and Vodráková, 2013; Sedmák and Hitka, 2007).

The literature presents (Taifa and Desai, 2017; Kovařík, 2009; Mokdad, Al-Ansari, 2009; Smardzewski, 2009; Malina et al., 2004; Krawczynski et al., 2003) different approaches how to establish the basic parameters of furniture, i.e. how to determine the optimal length, width and height of single bed area from the perspective of anthropometry and ergonomics, as designing of standard furniture needs direct involvement of anthropometric measurements. In our case, we took into account the development forecast of the anthropometric dimensions of population based on the secular trend. It is possible to create a universal design by adding the standard deviations (suitable for almost the entire population). Such an approach ensures the production of furniture with dimensions suitable for present and next generation.

The furniture price is closely related to two conditions - the recoverability of the furniture material, and the energy intensity of its processing. Wood is the most frequently used material (Dušak et al., 2015; Joščák et al., 2012). It affects the price because it is a 
completely renewable resource with low power demands in processing and with easily disposable waste. Wood as a material can be used in furniture manufacturing due to its unique harmony of its aesthetic and technical-technological properties, easy workability and strength.

If a company wishes to be efficient and successful in a constantly changing environment, understanding the buying behaviour of consumers is crucial for the company. Consequently, companies producing bed furniture must modify their calculation methods of pricing to be able to forecast their financial situation in those areas, expressing causal relation between the costs and respective performance (Barroso et al., 2005). Companies are subject to great competitive pressure. Offer exceeds demand in many areas, so it is important to focus on satisfying customer needs. The company needs to look for cost reduction option. Companies can only be competitive in the current dynamic environment by focusing on the future and not just on surveying the past.

Calculation formula represents the list of different types of costs that should be completed with a method of quantification of these items in relation to the calculated performance (Popesko, 2009). It is difficult to define the universal calculation formula for all products, because the enterprises compile calculation formula adapted to their own specific conditions (Macík, 2008).

The main task of SMEs is to innovate the products and to prepare new types of beds that can be used by large businesses in the future. The aim of this paper is to present the use of variators in the selected medium-size company engaged in furniture production when applying the most commonly used absorption costing in small and medium furniture enterprises.

\section{MATERIALS AND METHODS}

\section{MATERIJALI I METODE}

The forecast values of the relevant body dimensions of adult population (Table 1) were used to optimise the single bed dimensions for the needs of the present and future population. The sampling unit was composed of Slovak adult population, i.e. population over the age of maturity in terms of the growth process of people, i.e. 18 years and more. A total of 3.358 students from Slovak universities were involved. The sampling unit covered the population of the whole Slovak territory, which increases its representativeness. The technique of direct survey was used to acquire the empirical data. Data were collected by measurements of selected anthropometric characters (height, shoulder width).

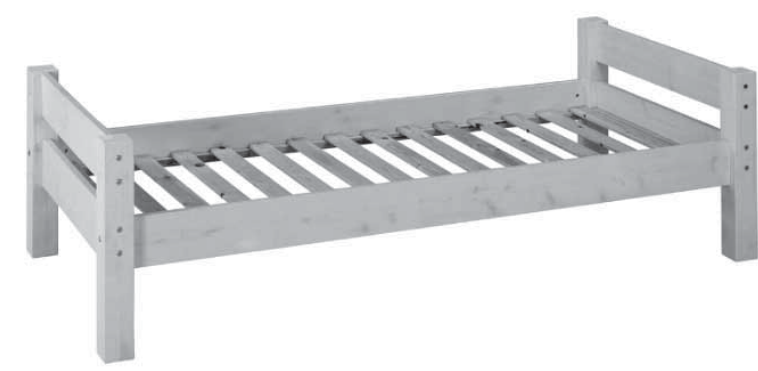

Figure 1 Single bed

Slika 1. Krevet za jednu osobu

Based on the findings of statistical properties of body dimensions of the current Slovak population, it was possible to determine the dimensions of a single bed corresponding to the population. The overall design of the single bed is given in Figure 1.

Body height of men $\left(\mathrm{BH}_{\mathrm{m}}\right)$ was used as the factor necessary to determine the dimensions, mainly the length of the lying surface. Comfortable sleep must be provided; therefore, comfort factor $(C F)$ was added. Then the total length of the lying surface $(L S)$ was calculated as follows (Prokopec, 1998):

$$
L S=B H_{\mathrm{m}}+2 s_{\mathrm{x}}+C F
$$

By summing the data stated in Eq. 1, it was possible to calculate the length of the single bed suitable for family house. Shoulder width $(S W)$ was crucial for determining the minimum width of the lying area $\left(b_{1}\right)$. It was necessary to enlarge the shoulder width by $50 \%$, and then two standard deviations were added due to trend development of population growth (Eq. 2).

$$
b_{1}=1.5 S W+2 s_{\mathrm{x}}+0.25\left(1.5 S W+2 s_{x}\right)(\mathrm{cm})
$$

The final length of the lying surface was calculated as $230.5 \mathrm{~cm}$. The final width of the lying surface was calculated as $102.3 \mathrm{~cm}$ and the final single bed height was calculated as $45.7 \mathrm{~cm}$. When analysing the dimensional characteristics of the current male Slovak population, it can be clearly stated that there is a positive secular trend. A body height increase of $+4.5 \%$ was recorded. In absolute terms, it represents an average increase of $+8 \mathrm{~cm}$. A similar development was observed in the arms width. The parameter increased by up to $6.7 \%$. It represents an increase of $+3 \mathrm{~cm}$. This might be the result of better nutrition, better psychosocial factors and socio-economic conditions of today's population (Sedmák and Hitka, 2007).

According to the author, this variator determines the degree of dependency of overhead costs spent on specific relative value. The relation for the determination of variation is as follow (Hradecký et al., 2008):

Table 1 Basic descriptive characteristics of the male population Tablica 1. Osnovne deskriptivne značajke muške populacije

\begin{tabular}{|l|c|c|c|c|c|c|}
\hline \multicolumn{1}{c|}{$\begin{array}{c}\text { Anthropometric sign } \\
\text { Antropometrijska značajka }\end{array}$} & \multicolumn{2}{c|}{$\begin{array}{c}\text { Original population } \\
\text { Izvorna populacija }\end{array}$} & \multicolumn{3}{c|}{$\begin{array}{c}\text { Current population } \\
\text { Današnja populacija }\end{array}$} \\
\hline Indicator / pokazatelj & $\bar{X}$ & $S_{\mathrm{x}}$ & $S_{\mathrm{x} \%}$ & $\bar{X}$ & $S_{\mathrm{x}}$ & $S_{\mathrm{x} \%}$ \\
\hline Physical standing height / fizička visina pri stajanju & 174.1 & 6.5 & 3.7 & 182.1 & 6.6 & 3.6 \\
\hline Shoulder width / širina ramena & 44.7 & 2.5 & 5.7 & 48.3 & 4.4 & 9.2 \\
\hline
\end{tabular}




$$
V=\frac{V P O C}{T O C}
$$

Where

$V$ - variator,

$V P O C$ - variable part of overhead costs,

TOC - total overhead costs.

A more detailed relation for the determination of variation is used by Potkány and Krajčírová (2015):

Where

$$
V=\frac{\frac{O C_{1}-O C_{0}}{O C_{0}}}{\frac{A B_{1}-A B_{0}}{A B_{0}}}=\frac{\frac{\Delta O C}{O C_{0}}}{\frac{\Delta A B}{A B_{0}}}
$$

$V$ - variator,

1 - budgeted period,

0 - initial period,

$O C$ - overhead costs,

$A B$ - allocation base.

Eq. 3 and Eq. 4 were used for the determination of individual items of overheads variators.

The starting point for price determination of single bed was a general costing formula. For the determination of direct costs of the product, we started from the consumption standards and time standards. Direct material consumption standard was supported by the technical documentation. Direct material consumption was set at $4.39 \mathrm{~m}^{2}$ for original bed dimensions of $200 \mathrm{~cm} \mathrm{x} 90$ $\mathrm{cm}$. As a consequence of bed dimension increase to $230.5 \mathrm{~cm} \times 102.3 \mathrm{~cm}$, consumption is increased to 7.17 $\mathrm{m}^{2}$. Unit acquisition price was planned at the level of $3.69 € / \mathrm{m}^{2}$. By multiplying these two factors, the amount of material consumption was quantified in value terms. The level of direct wages was determined through time consumption standards. The values were set by the enterprise in the amount of $3.20 €$ based on the actual need of 0.661 standard hour $(\mathrm{SH})$ per product. For the innovated product, with increased dimensions, the time consumption standards changed to the level of $0.85 \mathrm{SH} /$ product. The item of other direct costs (including the necessary number of connecting pins, cover caps and subsidiary material) remained unchanged.

In our case study, different allocation bases were used, so we were working with differentiated direct costing. Since all the costs were included in the calculation formula, it was the absorption costing (Poniščiaková, 2010).

\section{RESULTS AND DISCUSSION}

\section{REZULTATI I RASPRAVA}

Secular change seems to be a major characteristic of body physique of people in almost all countries of the world (Mokdad and Al-Ansari, 2009). Secular change was confirmed in Algeria, Australia, Cook Island, Hong Kong, India, Japan, Mexico, Poland, Spain, Turkey (Ozer, 2007; Carrascosa et al., 2004; Malina et al., 2004; Krawczynski et al., 2003; Bolstad et al., 2001; Ulijaszek, 2001; Ali et al., 2000; Pheasant, 1998; Leung et al., 1996; Mokdad, 1992; Roy \& Singh,
1992). Secular trend was proved by the anthropometric survey conducted in Singapore and Indonesia, too. According to the research, the average male figure grew by $5 \mathrm{~cm}$ in the last 19 years and the female by $6.9 \mathrm{~cm}$. These results are similar to other research (Mokdad and Al-Ansari, 2009). The results of anthropometric survey carried out on a sample of male and female Bahraini school children aged 6-12 years show a gradual increase from age 6 to age 12 in all body dimensions. Nutrition factors, socio-economic status, urbanization, physical activity, climate and psychosocial deprivation have contributed the growth in the dimensions of people in Singapore and Indonesia (Chuan et al., 2010). Living standards and dietary habits caused the increase in the average physical dimensions of students (Jung, 2005). Based on researches, it can be stated that the positive secular trend has a global impact.

The influence of these impacts is presented in our research for assessing the changes in production of a specific type of furniture - single bed. Items of production overheads were divided into technological and general section. The overhead tariff of $3.50 € / S H$ was determined for the technological production overheads. The overhead rates were also determined for other overheads. For general production overheads, the value of direct wages was selected as allocation base. For supply overhead costs, the amount of direct costs was selected, while for administrative overheads and sales and distribution overhead costs, it was the amount of production costs. Table 2 presents the initial situation and the calculation per single bed after the increase of its dimensions. In this case, we consider that the values of overhead rates have remained unchanged, despite the change in consumption of direct (technological) material and direct (technological) wages.

We determined new overhead rates by using of the variator method. The fact that the fixed part of the overheads remains unchanged and only the variable component of indirect costs changes was taken into account.

The variator value for supply overhead costs (SOC) was determined at the level of $68 \%$, in the general production overheads (GPO) at $43 \%$ and at $37 \%$ of the sales and distribution overhead costs (SDOC). Only fixed costs represent the administrative overheads $(A O C)$, and therefore the variator value is quantified at the level of 0 . Data on percentage increase, shown in Table 2, were used for this calculation. Changes in overheads volume after increase in bed dimensions were detected by the determination of increase in the cost components by the value of the variable component of relevant overheads and its percentage increase after the increase of dimensions. After level change recalculation of relevant overheads, these overheads were used for the determination of the new overhead rate. The original value of allocation base after dimension increase of single bed was used as the allocation base for the hypothetical production volume of 1.000 pieces. The determination of the current level of overhead rates on variator level is methodically determined as follows: 


$$
\begin{aligned}
& \Delta S O=[S O \cdot(0.68 \cdot 54.86 \%)+S O]= \\
& =20.360 \cdot 37.3 \%+20.360=27.954 € \\
& \% \text { SOC Rate }=\frac{27.954}{31.530} \cdot 100=88.66 \% \\
& \% \text { GPO Rate }=\frac{1.797}{4.110} \cdot 100=43.72 \% \\
& \% \text { AOC Rate }=\frac{31.240}{68.100} \cdot 100=45.87 \% \\
& \% \text { SDOC Rate }=\frac{15.994}{68.100} \cdot 100=23.49 \%
\end{aligned}
$$

Table 2 also presents the modified calculation of initial and new dimensions after application of new overhead rates.

Based on findings shown in Table 2, it can be concluded that, using of the traditional approach of compiling calculation, an increase of more than $52 \%$ can be expected in total output costs after the increase in bed dimensions. While preserving the original level of $15 \%$ profit, there would be an increase in the sales price of the product to the level of $156.63 €$ excluding VAT (which is an enormous increase of $52.59 \%$ ). This enormous increase would be caused by absence of overhead rates updates and proportionality of costs of a fixed nature in individual overheads items.

After the application of overhead rates determined by variators, the increase in total costs was about $21.92 \%$ (Table 2). The same percent increase occurred in the sales price of single bed at the constant relative profit level. More exact information on total product costs was obtained by applying the variator method in updating overhead rates.

With the increasing economic importance, customers are becoming increasingly demanding (Ma et al., 2017). These demands put pressure on businesses to establish innovations in their work, for example by outsourcing the maintenance operations for building equipment (David et al., 2017; Gilson et al., 2016). Factors such as price, performance, and design of the product are crucial for the customer when purchasing the product. Product safety and environmental impact have also become important criteria. The improvement of the customer satisfaction level is conducive to meeting customers' demands (Zheng et al., 2017). Accountability to customers in this area can be expanded in providing good service at a fair price, in handling complaints, in undertaking the communication with the customer, etc. If the company wants to be successful in long term, business activities must be systematic, controlled and based on purposeful innovation. Through successful innovation, companies try to get an important and long-term sustainable competitive advantage. In this context, sustainable profitability can be achieved through each segment of a value chain. One of these

\begin{tabular}{|c|c|c|c|c|c|c|}
\hline \multirow{3}{*}{ Costs / Troškovi } & \multirow{2}{*}{\multicolumn{2}{|c|}{$\begin{array}{l}\text { Initial dimensions } \\
\mathbf{2 0 0} \mathbf{~ c m ~ x ~} 90 \mathbf{c m} \\
\text { Početne dimenzije } \\
200 \times 90 \mathrm{~cm}\end{array}$}} & \multirow{2}{*}{\multicolumn{2}{|c|}{\begin{tabular}{|c|} 
Traditional approach \\
Tradicionalni pristup \\
New dimensions of \\
construction \\
$\mathbf{2 3 0 . 5} \mathbf{~ c m} \times \mathbf{1 0 2 . 3} \mathbf{~ c m}$ \\
Nove dimenzije kon- \\
strukcije $230,5 \times 102,3 \mathrm{~cm}$ \\
\end{tabular}}} & \multirow{2}{*}{\multicolumn{2}{|c|}{\begin{tabular}{|c} 
Variator method \\
Metoda varijatora \\
New dimensions of \\
construction \\
$\mathbf{2 3 0 . 5} \mathbf{~ c m} \times \mathbf{1 0 2 . 3} \mathbf{~ c m}$ \\
Nove dimenzije $k$ kon- \\
strukcije $230,5 \times 102,3 \mathrm{~cm}$ \\
\end{tabular}}} \\
\hline & & & & & & \\
\hline & $\begin{array}{c}\text { Calculation data } \\
\text { Podatci } z a \\
\text { izračun }\end{array}$ & $€$ & \begin{tabular}{|c|} 
Calculation data \\
Podatci za \\
izračun \\
\end{tabular} & $€$ & $\begin{array}{c}\text { Calculation data } \\
\text { Podatci za } \\
\text { izračun }\end{array}$ & $€$ \\
\hline Direct material / izravni materijal & $4.39 \mathrm{~m}^{2}$ & 16.20 & $7.17 \mathrm{~m}^{2}$ & 26.46 & $7.17 \mathrm{~m}^{2}$ & 26.46 \\
\hline Direct wages / izravne plaće & $0.661 S H / P U$ & 3.20 & $0.85 \mathrm{SH} / \mathrm{PU}$ & 4.11 & $0.85 \mathrm{SH} / \mathrm{PU}$ & 4.11 \\
\hline $\begin{array}{l}\text { Other direct costs / ostali izravni } \\
\text { troškovi }\end{array}$ & & 0.96 & & 0.96 & & 0.96 \\
\hline$\sum$ Direct costs / $\sum$ izravni troškovi & & 20.36 & & 31.53 & & 31.53 \\
\hline $\begin{array}{l}\text { Supply overhead costs } \\
\text { opći troškovi nabave }\end{array}$ & $100 \%$ & 20.36 & $100 \%$ & 31.53 & $88.66 \%$ & 27.95 \\
\hline $\begin{array}{l}\text { Production (technological) overheads } \\
\text { proizvodni (tehnološki) opći troškovi }\end{array}$ & $3.50 € / S H$ & 2.31 & $3.50 € / S H$ & 2.98 & $3.50 € / S H$ & 2.98 \\
\hline $\begin{array}{l}\text { Production (general) overheads } \\
\text { proizvodni opći troškovi }\end{array}$ & $50 \%$ & 1.60 & $50 \%$ & 2.06 & $43.72 \%$ & 1.80 \\
\hline Production costs / proizvodni troškovi & & 44.63 & & 68.10 & & 64.26 \\
\hline $\begin{array}{l}\text { Administration overheads } \\
\text { administrativni opći troškovi }\end{array}$ & $70 \%$ & 31.24 & $70 \%$ & 47.67 & $45.87 \%$ & 29.48 \\
\hline Product costs / troškovi proizvoda & & 75.87 & & 115.77 & & 93.74 \\
\hline $\begin{array}{l}\text { Sales and distribution overhead costs } \\
\text { opći troškovi prodaje i distribucije }\end{array}$ & $30 \%$ & 13.39 & $30 \%$ & 20.43 & $23.49 \%$ & 15.09 \\
\hline Total costs / ukupni troškovi & & 89.26 & & 136.20 & & 108.83 \\
\hline Profit $15 \% /$ dobit $15 \%$ & & 13.39 & & 20.43 & & 16.32 \\
\hline Price / cijena & & 102.65 & & 156.63 & & 125.15 \\
\hline
\end{tabular}
segments is the product and its price.

Compared to previous calculations, the difference is more than $27 €$ in favour of lower product price.

Table 2 Basic descriptive characteristics of the male population

Tablica 2. Osnovne deskriptivne karakteristike muške populacije 
Thus determined price is more acceptable for customers in terms of marketing principles. However, it still needs to be taken into consideration that the methodology of absorption costing was used, while it would be necessary to determine the overhead rates of individual groups also in the context of the complete product portfolio information. The most ideal solution is to use price decision-making principles of variable costing. This calculation is only made with the variable costs, where the most important element in comparing the efficiency of products is the level of contribution margin (difference between price and variable costs of product) (Synek et al., 2007). This calculation considers fixed costs as items, which are essential for ensuring the business operation in a particular period. These costs are subsequently added to the economic result for the whole period (by deduction from the total level of contribution margin). According to the author, variable costing is based on the assumption of fixed costs stability. By the calculation based on the cost breakdown to fixed and variable components, the knowledge of costs level can be achieved by performance unit and also evoked separately by other capacity scope decisions (Poniščiaková, 2010). In our case, the principle of variable costing was partially used. By the method of variators, the separation analysis of variable and fixed overheads was carried out. By updated overhead rates, the effect of proportionality of fixed costs was eliminated. Our aim was to eliminate undesirable inaccuracies caused by absolute and relative increase of fixed capital due to differences in capacity utilization (Poniščiaková, 2010).

\section{CONCLUSIONS}

\section{ZAKLJUČAK}

Secular trend of anthropometric dimensions of the adult population of Slovakia resulted in the consideration of dimensional changes in bed furniture. Based on the results of the long-term research of anthropometric measurements of Slovak adult population, it can be stated that the observed variables have been rising by about $4.5-5 \%$ during 25 years. Our research was further aimed at reconsidering these changes for standardised dimensions of a specific type of furniture - single bed. The dimensions we proposed are as follow (length $=230.5 \mathrm{~cm}$; width $=102.3 \mathrm{~cm}$, and height $=$ $45.7 \mathrm{~cm}$ ). With the change of dimensions, it was necessary to consider the increase of the production costs. The required principle is the choice of the calculation technique, which would allocate an adequate part of the overhead costs to the innovative products respecting the changes in direct costs. The ideal solution would be the implementation of variable costing principles. However, in this paper we have presented the traditional system of absorption costing with the possibility of using the methods of variators. Although the problem of allocating the overhead variable costs could not be avoided, this method eliminates the effect of proportionality of fixed costs. Our intention was to preserve the traditional and still preferred system of calcu- lations in the furniture companies in Slovakia. Using the variator method for each group of indirect costs in the areas of supply, production, sales, distribution, and administrative overhead, the change in direct costs $(+11.17 €)$ resulted in a change in overhead costs. Compared to the traditional absorption calculation, based on rate constancy, the minimum change in overhead costs $(+8.4 €)$ was caused by eliminating the impact of the proportionality of fixed costs.

The actual essence of innovation is the overheads rates update and monitoring of variator values. The essence of our proposal is to monitor overhead costs in the most detailed classification with the determination of the appropriate types of allocation bases. These allocation bases should reflect as accurately as possible the ratio of the change in overheads and the actual value of these bases. This dependence could be assessed using a correlation and regression analysis to determine the level of correlation coefficient. Correlation coefficient can be quantified by comparing the past data of the variables, such as the specific groups of overhead costs, and the considered allocation bases. Certainly, the ideal solution would be the parallel use of variable costing system, which would require additional investments in information base change, software support and personnel training. We consider our solutions to be innovative in the area of application of the available calculation methods.

\section{Acknowledgements - Zahvala}

This research was supported by APVV-16-0297, Updating of anthropometric database of Slovak population, and VEGA No. 1/0320/17, Economic and Social Context of European 20/20/20 Targets from the Viewpoint of Economy Low-Energy Houses.

\section{REFERENCES}

\section{LITERATURA}

1. Aaras, A.; Fostervold, K. I.; Ro, O.; Thoresen, M., 1997: Postural load during VDU work: a comparison between various work postures. Ergonomics, 40 (11): 1255-1268. http://dx.doi.org/10.1080/001401397187496.

2. Ali, M. A.; Uetake, T.; Ohtsuki, F., 2000: Secular changes in relative leg length in postwar Japan. American Journal of Human Biology, 12 (3): 405-416.

3. Barčić, A. P.; Motik, D.; Paluš, H.; Klarić, K.; Liker, K.; Oblak, L., 2016: Analysis of furniture selling places in Croatia, Slovenia and Slovakia. Drvna industrija, 67 (3): 257-262. http://dx.doi.org/10.5552/drind.2016.1545.

4. Barroso, M. P.; Arezes, P. M.; Da Costa, L. G.; Miguel, A., 2005: Anthropometric study of Portuguese workers. International Journal of Industrial Ergonomics, 35 (5): 401-410. http://dx.doi.org/10.1016/j.ergon.2004.10.005.

5. Bolstad, G.; Benum, B.; Rokne, A., 2001: Anthropometry of Norwegian light industry and office workers. Applied Ergonomics, 32 (3): 239-246. http://dx.doi.org/10.1016/S0003-6870(00)00067-3.

6. Buehlmann, U.; Bumfardner, M.; Sperber, M., 2013: How small firms contrast with large firms regarding perceptions, practices and needs in the U.S. secondary woodworking industry. BioResources, 8 (2): 2669-2680. http://dx.doi.org/10.15376/biores.8.2.2669-2680. 
7. Bumgardner, M.; Buehlmann, U.; Schuler, A.; Crissey, J., 2011: Competitive actions of small firms in a declining market. Journal of Small Business Management, 49 (4): 578598. http://dx.doi.org/10.1111/j.1540-627X.2011.00337.x.

8. Burgess-Limerick, R.; Plooy, A.; Ankrum, D., 1999: The influence of computer display height on head and neck posture. International Journal of Industrial Ergonomics, 23 (3): 171-179.

http://dx.doi.org/10.1016/S0169-8141(97)00033-4.

9. Carrascosa, A.; Yeste, D.; Copil, A.; Gussinye, M., 2004: Secular growth changes. Medicana Clinica, 123 (12): 445-451.

10. Chuan, T. K.; Hartono, M.; Kumar, N., 2010: Anthropometry of the Singaporean and Indonesian populations. International Journal of Industrial Ergonomics, 40 (6): 757-766. http://dx.doi.org/10.1016/j.ergon.2010.05.001.

11. Cook, C. J.; Kothiyal, K., 1998: Influence of mouse position on muscular activity in the neck, shoulder and arm in computer users. Applied Ergonomics, 29 (6): 439-443.

12. Cvičelová, M.; Beňuš, R.; Cifríková, M.; Hatiar, K., 2005: Evaluation of height parameters of the workplace base on anthropometric parameters. Working Medical, 57, 153-157.

13. David, R.; Banerjee, P.; Ponnam, A., 2017: Risks perceived regarding recruitment process outsourcing: stakeholder concerns. Journal of Global Operations and Strategic Sourcing, 10 (1): 112-136. http://dx.doi.org/10.1108/JGOSS-07-2016-0023.

14. Dušak, M.; Jelačić, D.; Zec, I., 2015: Position of wood processing and furniture manufacturing promotion in creation media. 26th International Conference on Wood Science and Technology: Proceedings of Scientific papers, Zagreb, Croatia.

15. Gilson, E.; Cugier, N.; Dureault, Ch.; Petrisor, T.; Pouyllau, H., 2016: Price prediction for outsourced facility management. Global Information Infrastructure and Networking Symposioum: Proceedings of Scientific papers, Porto, Portugal. http://dx.doi.org/10.1109/GIIS.2016.7814938.

16. Hitka, M.; Hajduková, A., 2013: Anthropometric optimization of bed furniture dimensions. Acta Facultatis Xylologiae Zvolen, 55 (1): 101-109.

17. Hradecký, M.; Lanča, J.; Šiška, L., 2008: Managerial accounting. Praha, CZ: Grada Publishing.

18. Joščák, P.; Vel'ká, I.; Poláčik, L., 2012: Axial bearing capacity of wood screws used in furniture constructions. Acta Facultatis Xylologiae Zvolen, 54 (1): 87-93.

19. Jung, H. S., 2005: A prototype of an adjustable table and an adjustable chair for schools. International Journal of Industrial Ergonomics, 35 (10): 955-969. http://dx.doi.org/10.1016/j.ergon.2005.04.007.

20. Kolena, B.; Vondráková, M., 2013: Nitra-Dražovce Osteological analysis of individuals from the medieval burial site around the church of St. Michal Archanjela in Nitra-Dražovce. Nitra, SR: Constantine the Philosopher University in Nitra.

21. Kotradyová, V.; Kaliňáková, B., 2014: Wood as material suitable for health care and therapeutic facilities. Advanced Materials Research, 1041: 362-366. http://dx.doi. org/10.4028/www.scientific.net/AMR.1041.362.

22. Kovařík, M., 2009: New aspects of interior ergonomics. International Conference Interiér: Proceedings of Scientific papers, Bratislava, SR.

23. Krawczynski, M.; Walkowiak, J.; Krzyzaniak, A., 2003: Secular changes in body height and weight in children and adolescents in Poznan, Poland, between 1880 and 2000. Acta Paediatrica, 92 (3): 277-282.
24. Kumar, S., 1994: A computer desk for bifocal lens wearers, with special emphasis on selected telecommunication tasks. Ergonomics, 37 (10): 1669-1678. http://dx.doi.org/10.1080/00140139408964944.

25. Lazar, J., 2012: Managerial accounting and controlling. Praha, CZ: Grada Publishing.

26. Leung, S. S.; Lau, J. T.; Xu, Y. Y.; Tse, L. Y.; Huen, K. F.; Wong, G. W.; Law, W. Y.; Yeung, V. T.; Yeung, W. K.; Leung, N. K., 1996: Secular changes in standing height, sitting height and sexual maturation of Chinese - the Hong Kong Growth Study. Annals of Human Biology, 23 (4): 297-306.

27. Ma, T.; Liu, Y.; Ge, Y. A., 2017: Comparative study of trade relations and the spatial-temporal evolution of geoeconomy between China and Vietnam. Sustainability, 9, 944. http://dx.doi.org/10.3390/su9060944.

28. Macík, K., 2008: Calculation and budgeting. Praha, CZ: ČVUT.

29. Malina, R. M.; Pena Reyes, M. E.; Tan, S. K.; Buschang, P. H.; Little, B. B.; Koziel, S., 2004: Secular change in height, sitting height and leg length in rural Oaxaca, Southern Mexico: 1968-2000. Annals of Human Biology, 31 (6): 615-633.

30. Mokdad, M., 1992: Secular change in stature of Algerians: the case of Ouled Djellal. Journal for Human Sciences, 3, 5-8.

31. Mokdad, M., 2002: Anthropometric study of Algerian farmers. International Journal of Industrial Ergonomics, 29, 331-341.

32. Mokdad, M.; Al-Ansari, M., 2009: Anthropometrics for the design of Bahraini school furniture. International Journal of Industrial Ergonomics, 39 (5): 728-735. http://dx.doi.org/10.1016/j.ergon.2009.02.006.

33. Naqvi, S. A., 1994: Study of forward sloping seats for VDT workstations. Journal of Human Ergology, 23 (1), 43-49.

34. Ozer, B. K., 2007: Growth reference centiles and secular changes in Turkish children and adolescents. Economics and Human Biology, 5 (2): 280-301. http://dx.doi.org/10.1016/j.ehb.2007.03.007.

35. Peteri, V., 2017: Bad enough ergonomics: A case study of an office chair. Sage Open, January-March: 1-11. http://dx.doi.org/10.1177/2158244016685135.

36. Pheasant, S., 1998: Bodyspace: Anthropometry, Ergonomics and the Design of Work. London, UK: Taylor \& Francis.

37. Poniščiaková, O., 2010: Costs and calculation in managerial accounting. Bratislava, SK: Iura Edition.

38. Popesko, B., 2009: Modern cost management methods. Praha, CZ: Grada Publishing.

39. Potkány, M.; Krajčírová, L., 2015: Calculation and budgeting. Zvolen, SR: Technical University in Zvolen.

40. Prokopec, M., 1998: Seating and lying upholstered furniture. Lignum, 2, 6-10.

41. Roy, G.; Singh, R., 1992: Parent-adult offspring correlations of anthropometric measurements in an urban Indian population. Journal of Human Ecology, 3 (2): 125-132.

42. Sedmák, R.; Hitka, M. 2007: Dynamika zmien vybraných antropometrických znakov populácie Slovenska. HRM\&E, 1 (3): 24-34.

43. Slovak Business Agency, 2016: Správa o stave malého a stredného podnikania $\mathrm{v}$ Slovenskej republike $\mathrm{v}$ roku 2015. Slovak Business Agency, (https://www.sbagency. $\mathrm{sk} /$ ) assessed on 13/09/2017.

44. Smardzewski, J., 2009: Antropotechnical aspects of furniture design. Drvna industrija, 60 (1): 15-21.

45. Synek, M.; Dvořáček, J.; Dvořák, J.; Kislingerová, E.; Tomek, G., 2007: Managerial economics. Praha, CZ: Grada Publishing. 
... Potkány, Hitka, Lorincová, Krajčirová, Štarchoň: Use of Variators in Applying the Cost ...

46. Taifa, I. W.; Desai, D. A., 2017: Anthropometric measurements for ergonomics design of students' furniture in India. Engineering Science and Technology, an International Journal, 20 (1): 232-239.

http://dx.doi.org/10.1016/j.jestch.2016.08.004.

47. Tokarčíková, E.; Kucharčíková, A., 2015: Diffusion of innovation. International Journal of Innovation and Learning, 17 (3): 359-370. http://dx.doi.org/10.1504/IJIL.2015.068467.

48. Ulijaszek, S. J., 2001: Socio-economic status, body size and physical activity of adults on Rarotonga, the Cook Island. Annals of Human Biology, 28 (5): 554-563.

49. Veselovský, J.; Kotradyová, V., 2009: Furniture designing and its limits. Annals of Warsaw University of Life Science, 69, 379-383.

50. Villanueva, M. B.; Sotoyama, M.; Jonai, H.; Takeushi, Y.; Saito, S., 1996: Adjustments of posture and viewing parameters of the eye to changes in the screen height of the visual display terminal. Ergonomics, 39 (7): 933-945. http://dx.doi.org/10.1080/00140139608964515.

51. Woolliscroft, P.; Cagáňová, D.; Čambál, M.; Makraiová, J., 2015: Multicultural collaborative team working as a driver for innovation in the Slovak automotive sector. Lecture Notes of the Institute for Computer Sciences, SocialInformatics and Telecommunications Engineering, 151: 9-15. http://dx.doi.org/10.1007/978-3-319-19743-2_2.

52. Zheng, Y.; Wang, J.; Tsai, S. B.; Li, G.; Wang, J.; Zhou, J., 2017: Research on Customer Satisfaction in Marine Cultural and Sustainable Tourism - A Case Study of Shanghai. Sustainability, 9 (6): 921.

http://dx.doi.org/10.3390/su9060921

\section{Corresponding address:}

doc. Ing. MILOŠ HITKA, PhD.

Technical University in Zvolen Faculty of Wood Sciences and Technology Department of Business Economics

T. G. Masaryka 24

96053 Zvolen, SLOVAKIA

e-mail: hitka@tuzvo.sk 